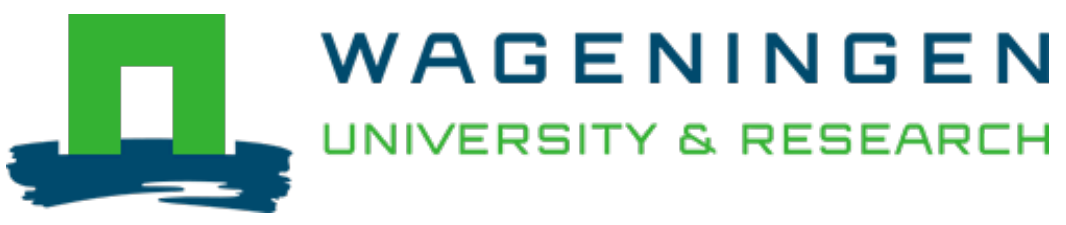

\title{
In search of genetic diversity in Rosa foetida Hermann in Iran
}

\section{Acta Horticulturae}

Samiei, L.; Naderi, R.; Khalighi, A.; Bushehri, A.A.; Mozaffarian, V. et al https://doi.org/10.17660/ActaHortic.2009.836.3

This article is made publicly available in the institutional repository of Wageningen University and Research, under the terms of article $25 \mathrm{fa}$ of the Dutch Copyright Act, also known as the Amendment Taverne. This has been done with explicit consent by the author.

Article $25 \mathrm{fa}$ states that the author of a short scientific work funded either wholly or partially by Dutch public funds is entitled to make that work publicly available for no consideration following a reasonable period of time after the work was first published, provided that clear reference is made to the source of the first publication of the work.

This publication is distributed under The Association of Universities in the Netherlands (VSNU) 'Article $25 \mathrm{fa}$ implementation' project. In this project research outputs of researchers employed by Dutch Universities that comply with the legal requirements of Article $25 \mathrm{fa}$ of the Dutch Copyright Act are distributed online and free of cost or other barriers in institutional repositories. Research outputs are distributed six months after their first online publication in the original published version and with proper attribution to the source of the original publication.

You are permitted to download and use the publication for personal purposes. All rights remain with the author(s) and / or copyright owner(s) of this work. Any use of the publication or parts of it other than authorised under article $25 \mathrm{fa}$ of the Dutch Copyright act is prohibited. Wageningen University \& Research and the author(s) of this publication shall not be held responsible or liable for any damages resulting from your (re)use of this publication.

For questions regarding the public availability of this article please contact openscience.library@wur.nl 


\title{
In Search of Genetic Diversity in Rosa foetida Herrmann in Iran
}

\author{
L. Samiei ${ }^{1}$, R. Naderi ${ }^{1}$, A. Khalighi ${ }^{1}$, A.-A. Bushehri ${ }^{2}$, V. Mozaffarian ${ }^{3}$, D. Esselink ${ }^{4}$ and \\ M.J.M. Smulders ${ }^{4}$ a \\ ${ }^{1}$ Dept. of Horticulture, College of Agriculture and Natural Resources, University of \\ Tehran, Iran \\ ${ }^{2}$ Dept. of Biotechnology, College of Agriculture and Natural Resources, University of \\ Tehran, Iran \\ ${ }^{3}$ Research Institute of Forest and Rangelands, Tehran, Iran \\ ${ }^{4}$ Plant Research International, Wageningen UR Plant Breeding, Wageningen, \\ The Netherlands
}

Keywords: microsatellite marker, yellow rose, identical genotypes

\begin{abstract}
Rosa foetida is a dense, erect shrub with bright yellow or scarlet flowers with a yellowish reverse petal. It is most abundant in South West Asia. In Iran $R$. foetida occurs mainly in the mountainous North and West regions. The species is the origin of the strong yellow color in hybrid roses, which was introduced into modern cultivars in 1900 through a single species hybridization event. In this study we have used 10 microsatellite markers to determine diversity in Rosa foetida accessions collected across Iran. To our surprise, nearly all samples collected were of the same genotype, even when collected at different sites. Only four different genotypes have been detected in total. The results are discussed in relation to breeding system, human influence and overall gene pool status.
\end{abstract}

\section{INTRODUCTION}

Rosa foetida is a dense erect shrub (up to $2 \mathrm{~m}$ ) with bright yellow or scarlet flowers with a yellowish reverse petal. It is most abundant in South West Asia from Turkey to Pakistan and Northwards to Georgia and the Tien Shan, It has been domesticated in Southern and Eastern Europe (Ercisli, 2005). In Iran R. foetida occurs mainly in the North and West region (Mozaffarian, 2005). It may be cultivated as an ornamental shrub or as a hedge along roadsides; otherwise it occurs scattered on slopes and sometimes in agricultural fields. The dried petals are traditionally used as decoction to relief abdominal pain or as part of a dish to reduce menstrual cramps of women (Ercisli, 2005).

$R$. foetida has been important for breeding of hybrid roses. The deep yellow color was transferred from $R$. foetida "Persian yellow" to the modern roses for the first time by Pernet-Ducher in 1898. The first yellow cultivar, 'Soleil d'Or' introduced in 1900, became a common ancestor of all the yellow cultivars from that time on (De Vries and Dubois, 1978). The bright yellow and orange color in Hybrid Tea roses is derived from this single introgression event. De Vries and Dubois (1978) made a new introgression to enlarge the genetic basis of yellow, using a cross with $R$. foetida "Austrian Briar".

The germplasm of $R$. foetida has not been studied in detail, and it is not used in breeding programs nowadays. Here we set out to study the genetic diversity of the $R$. foetida germplasm of Iran. We have phenotypically identified three types of $R$. foetida in Iran; the most common type with bright yellow flowers with 5 petals, a second one with a scarlet flower with a yellowish reversed petal which is very similar to the common $R$. foetida except for the flower color, which we refer to as $R$. foetida 'bicolor', and the third one which has a stronger growth habit compared to the last two ones, referred to as 'double flower' $R$. foetida.

Microsatellite (SSR) markers are ideal tools for population genetic studies as they are PCR-based markers, genetically defined, co-dominant and multiallelic. They have

${ }^{\mathrm{a}}$ rene.smulders@wur.nl 
been developed in rose (Esselink et al., 2003; Zhang et al., 2006; Hibrand-Saint Oyant et al., 2008) and were used to estimate genetic variation between hybrid tea and rose rootstock varieties (Esselink et al., 2003), between oil-bearing Rosa damascena Mill. accessions (Babaei et al., 2007), and to understand the reproduction system in dogroses (Nybom et al., 2006). In the present study, we have used microsatellite markers to determine diversity in $R$. foetida accessions collected across Iran. The results are discussed in relation to breeding system, human influence, and overall gene pool/species status.

\section{MATERIALS AND METHODS}

$R$. foetida samples were collected from single plants in agricultural fields or in remote places near mountainous areas across Iran, notably from Tehran, Qazvin, Ardabil, East Azarbaijan, Hamedan and Kurdistan provinces (Fig. 1) where R. foetida had been reported to occur (Rechinger, 1982). Based on morphology 10 individuals belonged to $R$. foetida and two to $R$. foetida var "bicolor". Two plants belonged to R. foetida but clearly had a double flower. This variant has not been described before. Three $R$. foetida samples were obtained from the botanical garden of Wageningen University; one that originally came from Turkey (G13) and the other two from unknown origin in Asia (G14, G15; Table 1). DNA was extracted using the DNeasy Plant Mini Kit, (Qiagen).

Ten robust microsatellite markers were selected from Esselink et al. (2003) representing different linkage groups and highly polymorphic in Hybrid Teas (Smulders et al., 2009) and in other Rosa species. Fluorescently labeled (6FAM, HEX or NED) primer pairs were amplified in three multiplexes using the Qiagen PCR multiplex kit (Westburg, The Netherlands). The PCR program consisted of an initial denaturation step at $95^{\circ} \mathrm{C}$ for $15 \mathrm{~min}$ followed by 30 cycles of $94^{\circ} \mathrm{C}$ for $30 \mathrm{~s}$, ramp to $50^{\circ} \mathrm{C}\left(1^{\circ} \mathrm{C} / \mathrm{s}\right), 50^{\circ} \mathrm{C}$ for $30 \mathrm{~s}$, ramp to $72^{\circ} \mathrm{C}\left(1{ }^{\circ} \mathrm{C} / \mathrm{s}\right), 72^{\circ} \mathrm{C}$ for $2 \mathrm{~min}$; and a final extension at $72^{\circ} \mathrm{C}$ for $10 \mathrm{~min}$. Fluorescent amplification products were detected using an ABI Prism 3700 DNA Analyzer (Applied Biosystems) and all samples were genotyped in accordance with reference alleles for each locus, as described in Esselink et al. (2003), using Genotyper 3.5 NT software (Applied Biosystems). The presence (1) or absence (0) of each microsatellite allele was recorded for each genotype.

Genetic distances were calculated as Dice similarities on the basis of dominant scoring of individual alleles in NTSYS 2.1 (Applied Biostatistics). This enables analysing plants which are polyploid. The accessions were clustered using the unweighted pair group method using arithmetic averages (UPGMA) module of NTSYS.

\section{RESULTS}

The amplification of DNA from $17 R$. foetida accessions using 10 microsatellite loci produced between $2(\mathrm{RhD} 221)$ and 7 (RhP50) alleles per locus, and on average 4.3 alleles per locus (Table 2). Observed heterozygosity varied between 0.07 and 0.73 . A similarity matrix was used to generate a UPGMA dendrogram, which clearly reflects which samples are genetically identical (Fig. 2). The large majority (13/17) of the samples had an identical genotype. This group (A in Fig. 2) included samples from Tehran (G1, G2, G6), Qazvin (G3), East Azarbaijan (G4, G5, G7, G8), and Kurdestan provinces (G9), and the accession from the Dutch botanical garden with Asian origin (G14). In addition, the two plants from var "bicolor" also belonged to this group. The "bicolor" plants are thus probably mutants of the 'common' $R$. foetida. Three of the accessions of this group (G10, G16 and G17) had the same set of alleles, but one or two alleles did not amplify clearly (which leads to less than $100 \%$ identity even though no allele is different, hence the small distance in the dendrogram). Group B consisted of the two samples of $R$. foetida "double flower" collected in East Azarbaijan and Ardabil provinces. These samples were identical to each other. Finally, two samples were unique within this dataset: G13 from Turkey and G15 from the Wageningen collection but originally of Asian origin. They actually had very few alleles in common with each other and with the other samples in this study. 


\section{DISCUSSION}

It appears that most $R$. foetida samples from Iran are of one genotype, even though they were sampled from natural locations more than $500 \mathrm{~km}$ apart. As the plants are heterozygous, the obtained data suggest that clones of one genotype were spread into distant geographic regions of Iran and have been successfully vegetatively propagated, probably for centuries.

The reason for the observed dominance of one $R$. foetida genotype is not so clear but it is known that $R$. foetida is one of the species that is hard to bear seed (Koopman et al., 2008; Roberts, 1977). Indeed, we have observed very few seeds on the plants that we have sampled, and we could not germinate the seeds, so these observations support the notion that this $R$. foetida genotype predominantly propagates vegetatively. It seems likely that long distance movement may have been mediated by humans. Indeed, people do use $R$. foetida. However, they collect parts from plants that grow in the wild or happen to grow in fields. There currently is no known cultivation of these plants.

One of the samples from Wageningen botanical garden (G14) was exactly the same as the dominant Iranian genotype, although it probably was collected elsewhere in Asia. This suggests that the distribution area of this genotype could be (much) larger. However, a systematic collection of samples would be necessary to investigate this supposition.

Two $R$. foetida var "bicolor" samples were included in our analysis. They represent a rare type of $R$. foetida in Iran. They have exactly the same allelic profile as the dominant $R$. foetida genotype. This means that it is a color mutant of the dominant $R$. foetida. Color mutants are due to a mutation in one of the genes involved in the synthesis of the color components. The chance of detecting the mutation with molecular markers is very small (Weising et al., 1995). Indeed, no mutation-related polymorphisms were observed with microsatellites in peach (Testolin et al., 2000) and rose (Debener et al., 2000). Therefore, it can be expected that mutants have the same microsatellite fingerprint as the original variety and other mutants derived from the same variety (Esselink et al., 2003). Smulders et al. (2009) found identical microsatellite genotypes for mutants groups in a study of a large collection of hybrid rose cultivars. The only other genotype among the Iranian samples was the "double flower" variant of $R$. foetida.

Although Iran is considered one of the places of origin of $R$. foetida, no variation in genotypes was observed and it appears that genetic background of $R$. foetida of Iran is narrow. It could be that Iran is not the centre of origin of this species. Indeed, the two other samples from outside Iran (one from Turkey, the other one with unknown Asiatic origin) were genetically quite different. This implies that there is at least some genetic variation within $R$. foetida. Whether other genotypes also spread vegetatively across a large region is currently unknown.

This is the first study to identify genetic differences among $R$. foetida accessions. A thorough inventory in South West Asia and the inclusion of more accessions with desirable traits will be an essential step towards achieving $R$. foetida breeding objectives.

\section{Literature Cited}

Babaei, A., Tabaei-Aghdaei, R., et al., 2007. Microsatellite analysis of Damask rose (Rosa damascena Mill.) accessions from various regions in Iran reveals multiple genotypes. BMC Plant Biol. 7:12.

Debener, T., Janakiram, T. and Mattiesch, L. 2000. Sports and seedlings of rose varieties analysed with molecular markers. Plant Breeding 119:71-74.

Ercisli, S. 2005. Rose (Rosa spp.) germplasm resources of Turkey. Gen. Res. Crop Evol. 52:787-795.

Esselink, G., Smulders, M.J.M. and Vosman, B. 2003. Identification of cut rose (Rosa hybrida) and rootstock varieties using robust sequence tagged microsatellite site markers. Theor. Appl. Genet. 106:277-286.

Hibrand-Saint Oyant, L., Crespel, L., Rajapakse, S., Zhang, L. and Foucher, F. 2008. Genetic linkage maps of rose constructed with new microsatellite markers and 
locating QTL controlling flowering traits. Tree Genet. Genom. 4:11-23.

Koopman, W.J.M., Wissemann, V., et al., 2008. AFLP markers as a tool to reconstruct complex relationships: A case study in Rosa (Rosaceae). Am. J. Bot. 95:353-366.

Mozaffarian, V. 2005. Trees and shrubs of Iran. Farhang-e-Moaser, Tehran. (in Persian)

Nybom, H., Esselink, G.D., et al., 2006. Unique genomic configuration revealed by microsatellite DNA in polyploid dogroses, Rosa sect. Caninae. J. Evol. Biol. 19:635648.

Rechinger, K. 1982. Flora Iranica. No. 152, Rosaceae II-Rosa. Akademische Druck-UVerlagsanstalt, Graz.

Roberts, A.V. 1977. Relationship between species in the genus Rosa, section Pimpinellifoliae. Bot. J. Linn. Soc. 74:309-328.

Smulders, M.J.M., Esselink, D., Voorrips, R.E. and Vosman, B. 2009. Analysis of a database of DNA profiles of 734 hybrid tea rose (Rosa hybrida) varieties. Acta Hort. 836:169-174.

Testolin, R., Marrazzo, T., et al., 2000. Microsatellite DNA in peach (Prunus persica L. Batsch) and its use in fingerprinting and testing the genetic origin of cultivars. Genome 43:512-520.

Vries, D.P. de and Dubois, L.A.M. 1978. On the transmission of the yellow flower colour from Rosa foetida to recurrent flowering Hybrid Tea-roses. Euphytica 27:205-210.

Weising, K., Nybom, H., Wolff, K. and Meyer, W. 1995. DNA fingerprinting in plants and fungi. CRC Press, Boca Raton, Florida.

Zhang, L.H., Byrne, D.H., et al., 2006. Microsatellite marker development in rose and its application in tetraploid mapping. J. Am. Soc. Hort. Sci. 131:380-387.

$\underline{\text { Tables }}$

Table 1. Geographical origins of $R$. foetida accessions used in this study.

\begin{tabular}{lccc}
\hline Genotype & Province & Site of collection & Type of $R$. foetida \\
\hline G1 & Tehran & Shahrestanak & Foetida \\
G2 & Tehran & Gajere & Foetida \\
G3 & Qazvin & Qazvin & Foetida \\
G4 & East Azarbaijan & Ishlagh & Foetida \\
G5 & East Azarbaijan & Ahar & Foetida \\
G6 & Tehran & Velayatrud & Foetida \\
G7 & East Azarbaijan & Miyane & Foetida \\
G8 & East Azarbaijan & Ishlagh & Foetida (bicolor) \\
G9 & Kurdestan & Sanandaj & Foetida (bicolor) \\
G10 & Kurdestan & Sanandaj & Foetida \\
G11 & East Azarbaijan & Ishlagh & Foetida (double) \\
G12 & Ardabil & Ardabil & Foetida (double) \\
G13 & Turkey & Wageningen (N1.) & Foetida \\
G14 & Asia & Wageningen (N1.) & Foetida \\
G15 & Asia & Wageningen (N1.) & Foetida \\
G16 & Hamedan & Hamedan & Foetida \\
G17 & Kurdestan & Sanandaj & Foetida \\
\hline
\end{tabular}


Table 2. Characteristics of the results of the microsatellite loci.

\begin{tabular}{lcccc}
\hline Locus & $\begin{array}{c}\text { No. of } \\
\text { alleles }\end{array}$ & $\begin{array}{c}\text { Alleles found } \\
\text { (size in bp) }\end{array}$ & $\begin{array}{c}\text { Expected } \\
\text { heterozygosity }\end{array}$ & $\begin{array}{c}\text { Linkage } \\
\text { group }\end{array}$ \\
\hline P518 & 4 & $124,135,138,140$ & 0.57 & $?$ \\
AB40 & 3 & $201,249,252$ & 0.36 & 4 \\
O517 & 4 & $259,261,265,269$ & 0.56 & 1 \\
EO506 & 3 & $192,198,213$ & 0.67 & 3 \\
D221 & 2 & 217,223 & 0.07 & 4 \\
AB73 & 6 & $151,155,161,165,169,185$ & 0.70 & 7 \\
D201 & 6 & $194,195,197,198,201,202,204$ & 0.73 & $?$ \\
B303 & 3 & $117,119,128$ & 0.53 & $?$ \\
E2b & 5 & $165,168,174,177,183$ & 0.57 & 6 \\
P50 & 7 & $257,266,287,293,302,332,344$ & 0.71 & 3 \\
\hline Total & 43 & \multicolumn{5}{c}{0.5476} & \\
\hline Average & \multicolumn{5}{c}{} \\
\hline
\end{tabular}

$\underline{\text { Figures }}$

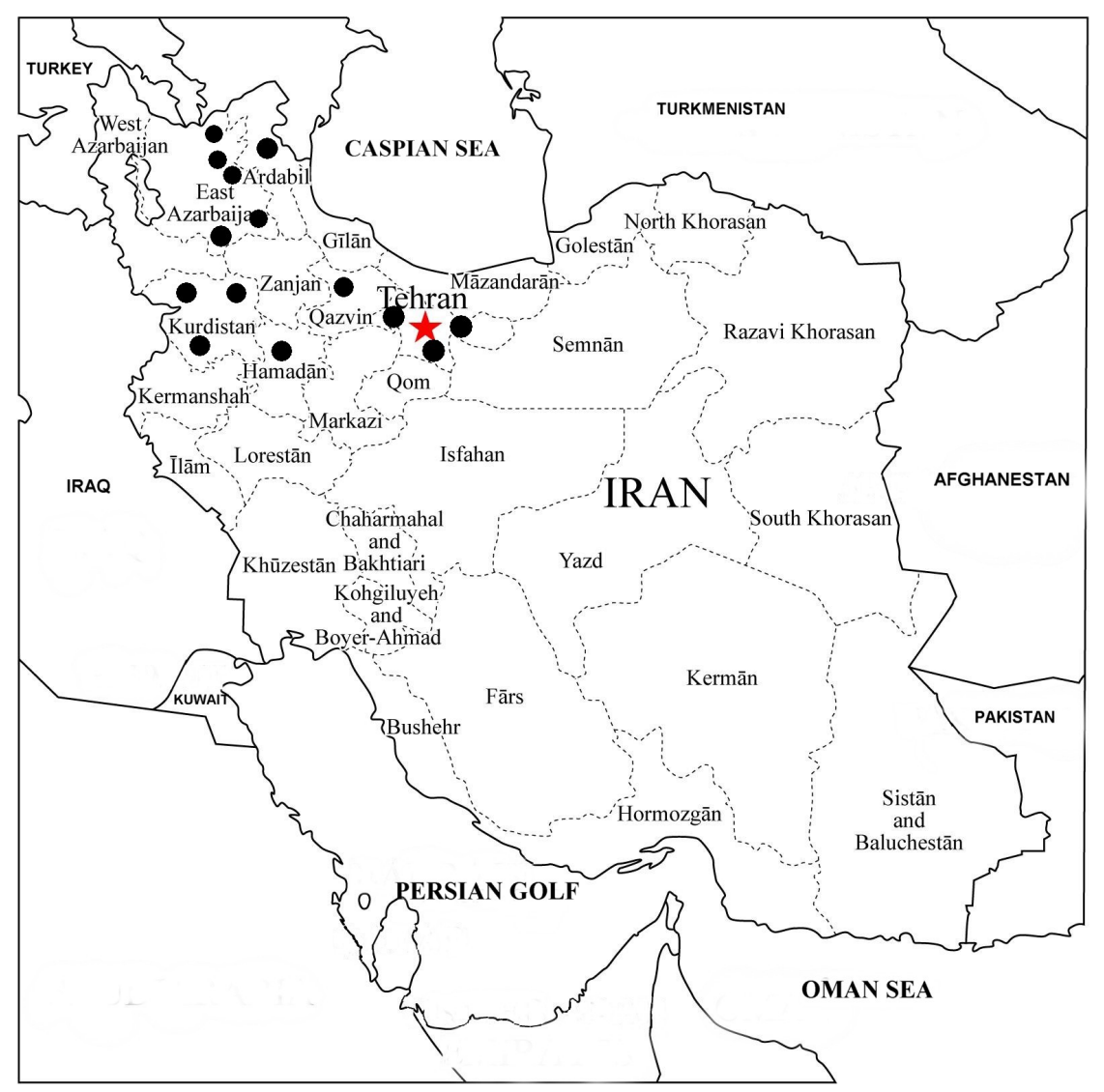

Fig. 1. Locations of the Iranian R. foetida samples. 


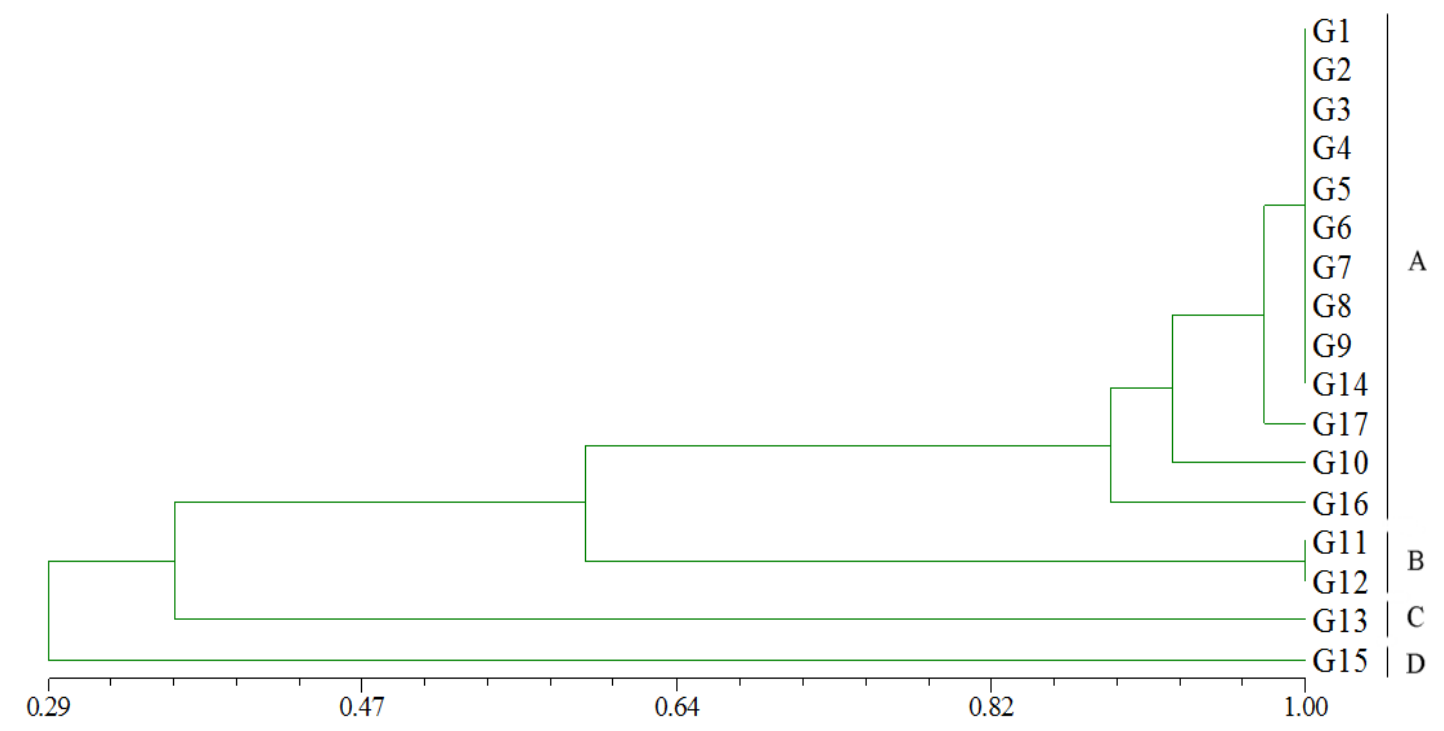

Fig. 2. UPGMA cluster analysis of all $R$. foetida accessions using 10 microsatellite markers. Note that 1 (similarity) $=$ genetically identical . 